\title{
Chain of custody certification : an assessment of Ghanaian timber sector
}

\begin{abstract}
Although Europe represents a major market for Ghana, information on how local companies are addressing chain of custody certification is scarce. A survey of 103 timber firms, in particular, was conducted in order to determine the current status of chain of custody certification in Ghana. Results collated indicate that the readiness to adopt chain of custody certification among the sector was low. The lack of stakeholders' awareness and price premium was cited as the primary reasons deterring the sector from adopting certification. This study analysis suggests that company size is an important variable to be considered when analyzing the adoption of chain of custody certification by timber companies. This study shows that an increasing adoption of chain of custody certification among the sector in Ghana can be realised with good stakeholder consultations and resource rights.
\end{abstract}

Keyword: Chain of custody; Timber; Ghana 